\title{
Research on the Current Situation and Countermeasures of College Dance Education
}

\section{Luo Maocuo}

School of Music, Hexi University, Zhangye, Gansu, 734000

\author{
Keywords: College Dance Education, Education Status, Countermeasures Study
}

\begin{abstract}
The promotion of college dance education accompanied by education reform is constantly innovating in teaching concepts and methods. In particular, the promotion of quality education in colleges and universities has promoted the development of dance education to a new stage, and also put forward new requirements for dance education. In the process of organizing dance teaching, teachers need to consider a lot of teaching factors, and start from the actual situation of students, so as to clarify the shortcomings of current dance teaching, and further promote the continuous innovation of dance education. The paper comprehensively analyzes the current situation of college dance teaching, and elaborates on the problems revealed by dance teaching. Then, based on this, it proposes targeted reconstruction measures to fundamentally improve the effectiveness of college dance education, and then promote The comprehensive literacy of the students’ dance has been significantly improved.
\end{abstract}

\section{Introduction}

With the development of society and the in-depth development of quality education, the social influence of dance education is growing, and it has gradually become an important part of China's education. Ted Shaws, a world-famous dance educator, said: "I believe that true dance education is also a comprehensive education for people - his body and mind, emotions will be nourished, edified and exercised in dance." Thus, dance education It can not only cultivate students' sentiment, improve their quality, but also appreciate their artistic appreciation and participation. At the same time, they can help students develop their intelligence, tap their inner potential, and have rich artistic emotions and imaginations, which will eventually lead to comprehensive development. Therefore, it is imperative to set up dance courses in colleges and universities and carry them forward.

\section{Problems in the dance education work of colleges and universities}

Since the dance education major was introduced into the education and teaching of colleges and universities, dance education has become a professional, unified and purposeful educational work, which has received much attention throughout the country. The dance education in colleges and universities is different from the dance education activities carried out by non-dance majors. The dance education in colleges and universities is strongly supported by the state and government departments, and is strongly supported by the education departments of the universities and highly recognized by the masses of the society. However, judging from the development of college dance education, many dance educators and dance students regard dance as a simple physical movement such as shaking hands, twisting their legs, lifting their legs, neglecting dance education and dance performances. The profound connotation and intrinsic value of dance, the dance course is regarded as a course of physical exercise. Even some college dance teachers are affected by many factors such as the times and the environment, which reduces the difficulty of dance teaching. It fails to develop the value and talent cultivation value of the dance itself, and reduces the true meaning and value of dance education.

With the increasing emphasis on the quality of college dance education in China's government departments and education, the lack of education in the structure of education and the content of 
education has become increasingly prominent, leading to relatively narrow knowledge of dance teaching activities. Teachers neglect the cultivation of students' emotional attitudes and values, neglect the actual situation of students' own development in the whole teaching activities, reduce students' interest in learning, and enable students to imitate the dance movements of teachers throughout the learning process. Dance is not only a manifestation of body language, but also a kind of conveyance of thoughts, emotions, cultural connotations and ideals. Only when dance performers are truly integrated into dance performances can the true value of dance education be revealed. However, judging from the actual development of dance education in contemporary colleges and universities, when college dance teachers carry out dance teaching activities for students, they only pay attention to whether the students' physical movements are expressed in place, ignoring the thoughts and emotions that students present during the performance process, resulting in The performance of the dance performance is "like and not like God", which makes the dancers become the "robots" of dance movements, and loses the true meaning and value of the dance performances.

The smooth development of the dance education curriculum is inseparable from the soundness and perfection of the dance infrastructure. The dance education courses in colleges and universities need to provide students with dedicated dance classrooms and teaching equipment in line with the curriculum teaching, providing a material basis for the development of college dance education. However, judging from the actual situation of the current dance education work in our country, the university does not provide students with special places for dance learning and training; without the actual situation of the dance teaching content, the teaching equipment used in the dance course is added in time; Some dance teachers are uneven and unable to provide students with quality teaching content.

\section{Optimization strategies and methods of college dance teaching}

As an important base for talent training and talent export, colleges and universities introduce dance into the educational activities of colleges and universities, fully implement the training of dance professionals, and lay a foundation for the output of professional dance talents, so that the dance culture can have a long history and do a good job in traditional culture. Inherit and carry forward work, enrich the connotation of campus culture, and promote social progress and development. In order to ensure the smooth development of college dance teaching activities, highlight the teaching significance and practical connotation of college dance teaching activities, and clarify the basic goals and practical values of college dance teaching. College teachers should first understand the dance education and fully understand the true dance education. Connotation, training professional dance talents, rather than cultivating talents who only perform mechanical dance performances, need to make students fully aware of the purpose of dance performances. For example, ethnic dance is one of the important contents of college dance teaching. Through the national dance performance teaching activities for college students, before the basic dance skills are taught, the formation and development process of the national dance is explained to the students, so that the students can understand the dance more deeply. Skills, improve students' understanding and cognition of dance skills, enable students to correctly grasp the national dance performance skills while understanding the profound connotation of national dance, and improve the students' aesthetic awareness and values while cultivating college students' dance professional skills. College students become the successors and promoters of national dance.

In the teaching activities of colleges and universities, dance teaching is different from conventional disciplines. The discipline cannot be rigidly adhered to the traditional syllabus, and it is necessary to use a method with strong openness, flexibility and simulation to carry out teaching activities. Judging from the development of college dance education, the syllabus planning model is widely used in all kinds of education in China. This kind of teaching mode makes the professional curriculum develop towards the expected goal to some extent, and at the same time makes the teaching content become rigid and rigid. The entire teaching process lacks flexibility and flexibility, and lacks humanistic teaching elements. In view of the problem that college dance education still stays in the syllabus planning mode, colleges and universities should first reform the dance teaching 
and deepen the "student-oriented" development strategy. According to the actual needs of students, combined with the actual teaching conditions of colleges and universities, scientifically set dance teaching materials. For the students of different classes and different levels, arrange the corresponding dance teaching content to enhance the pertinence, purpose, accuracy and applicability of the dance education content. Secondly, colleges and universities should take the actual teaching structure of the school as a breakthrough. According to the requirements of the development of the times, combined with the needs of students' physical and mental growth, understand the development direction of the dance profession and dance industry in the future society, and establish a long-term development awareness. The current teaching content and teaching system are reformed and innovated, so that the teaching content and education system cater to the requirements of the times, conform to the laws of physical and mental development of students, and the development direction of dance and dance industries.

College dance education work is inseparable from the support of infrastructure. In order to ensure the smooth development of dance teaching activities in colleges and universities, and to reduce the influence of external factors on the dance education curriculum, it is necessary for universities to vigorously strengthen the investment in dance professional courses and do a good job in the investment and distribution of teaching funds. First, colleges and universities should correctly allocate the allocation ratio of teaching funds according to the actual situation of the college, do a good job in the investment of teaching funds, and have sufficient construction funds for the construction of dance education infrastructure. Second, colleges and universities purchase infrastructure. At the time, the actual development of college dance courses should be based on the actual situation, purchase the corresponding dance equipment to prevent the waste or missing of the dance equipment; Third, rationally plan the dance education venue to ensure the safety and stability of the dance education environment. Sexuality and rationality; Fourthly, vigorously strengthen the introduction of dance education talents, regularly train and guide the dance teachers of the school, strengthen communication and exchanges between dance teachers of various universities, and build a high-quality, high-level dance education team. In view of the teaching problems existing in college dance education, colleges and universities must pay great attention to this. Especially in the era of quality education, college dance education must achieve innovation, so as to maximize the teaching work to achieve the desired results. First of all, we need to optimize from the curriculum to enhance humanity and pragmatism. Colleges and universities need to set dance education as an elective course, and classify it into a single door, constantly improve the structure of the curriculum, pay attention to the teaching of theoretical courses, so that the dance education can be unified, the categories are reduced, and the teaching time is appropriately increased. A systematic and comprehensive understanding of dance education. In addition, it should be noted that dance education must be based on quality education and cultivate students' artistic appreciation quality. Under the premise of the dance theory curriculum, it is necessary to add a dance art appreciation course so as to maximize student learning. Enthusiasm makes it possible to feel the artistic charm of dance and to perceive the aesthetic value of its own dance.

The effective development of dance education in colleges and universities is inseparable from the full support of teachers, so the quality of teachers is the most important foundation at this stage. From a holistic perspective, college dance education must constantly optimize its own teaching team construction according to its own actual situation, and actively explore the current dance teaching strategies suitable for the students. The dance education in colleges and universities in China must be optimized according to China's national conditions, and a dance teaching strategy that conforms to the current actual situation should be drawn up. For college dance education, this is a comprehensive and comprehensive subject content, so it has extremely high requirements for teachers. They must not only have professional and exquisite skills, but also must have a profound cultural heritage. What's more important is that dance teachers also need to have excellent sentiments. They can love and dedicate their lives to their education. They should regard dance education as a lifelong career, so that they can play a good role model for students and become their model. . For college leaders, they need to entrust the dance teachers with a heavy responsibility, 
respect the role of their teaching process, and maximize the functionality of the teachers themselves, so that they can become the backbone of dance education, so that teachers can better organize education. Give full play to its educational enthusiasm and improve the quality of classroom teaching. Dance teachers need to constantly enrich their skills. They need to keep up with the times. In the process of learning new dance knowledge, special training must be arranged. Through the continuous improvement of theoretical knowledge, teachers improve their theoretical level. On this basis, teachers need to implement theoretical knowledge into teaching practice, so as to promote the demand for college dance lessons, and further promote the significant improvement and improvement of college dance quality. Select more outstanding talents for colleges and universities.

\section{Conclusion}

Reform is an important measure to promote dance education in colleges and universities. It is necessary for colleges and universities in China to pay more attention to the dance profession, update the teaching thoughts of college dance teachers in a timely manner, correct the teachers' attitudes towards dance courses, and optimize the teaching content and teaching structure of dance courses. Adhere to the "student-oriented" teaching principle, integrate the dance teaching model according to the actual needs of students, increase the investment of education funds, implement the input of dance education infrastructure, regularly train and guide teachers, and promote college dance. The functionality of teaching.

\section{Acknowledgements}

Fund Project: Rescue and research on the data of folk music and old art in Hexi Corridor.

\section{References}

[1] Wang Mingquan. Exploring the problems and countermeasures of the dance education in the normal school [J]. Music Time and Space, 2015, (19): 145.

[2] Zhao Ming. Analysis of the Problems and Countermeasures of College Dance Education in China[J]. Art Science and Technology,2015,28(10):292.

[3] Huang Ya. Analysis of the current situation of the curriculum of dance majors in colleges and universities in Hunan Province and countermeasures [D]. Changsha: Hunan Normal University, 2013.

[4] Li Dingxin. Problems in the Dance Education of Colleges and Universities and Countermeasures[J]. Voice of the Yellow River, 2012, (16): 85.

[5] Sun Bo. Taking the music and dance education to start thinking about the way of college art education reform in China [J]. Young Literature Writer, 2010 (15). 